\title{
Detrimental effects of uterine disease and lipopolysaccharide on luteal angiogenesis
}

\author{
Zeravan A Mohammed1,*, Robert S Robinson"3, Rachel Harris³, Yasmin McLaughlin³, Kaitlin E M Turnbull³, \\ George E Mann² and Kathryn J Woad³
}

${ }^{1}$ College of Veterinary Medicine, University of Duhok, Kurdistan Regional Government and Scientific Research, Kurdistan, Iraq 2School of Biosciences, University of Nottingham, Sutton Bonington Campus, Loughborough, Leicestershire, UK

${ }^{3}$ School of Veterinary Medicine and Science, University of Nottingham, Sutton Bonington Campus, Loughborough, Leicestershire, UK

Correspondence should be addressed to K J Woad: katie.woad@nottingham.ac.uk

*(Z A Mohammed and R S Robinson contributed equally to this work)

\begin{abstract}
Reproductive tract inflammatory disease (RTID) commonly occurs after the traumatic events of parturition and adversely affects follicular function. This study is the first to describe the cellular and steroidogenic characteristics of corpora lutea from cattle with RTID and the effects of pathogen-associated molecular patterns (PAMPs) on luteal angiogenesis and function in vitro. Luteal weight $(P<0.05)$ and progesterone content $(P<0.05)$ were reduced $(1.2$-fold) in cows with RTID, accompanied by reduced CYP11A $(P<0.05)$, HSD3B $(P<0.01)$ and STAR $(P<0.01)$ protein expression. Immunohistochemistry revealed that luteal vascularity (VWF) and pericyte (ACTA2) coverage were $>3$-fold lower in RTID cows $(P<0.05)$. To link these observations to bacterial infection and determine specificity of action, a physiologically relevant luteal angiogenesis culture system examined the effects of PAMPs on endothelial cell (EC) network formation and progesterone production, in the presence of pro-angiogenic factors. Luteal EC networks were reduced $\leq 95 \%(P<0.05)$ by lipopolysaccharide (LPS, toll-like receptor (TLR) 4 agonist) but not by TLR2 agonists lipoteichoic acid or peptidoglycan. Conversely, progesterone production and steroidogenic protein expression were unaffected by PAMPs $(P>0.05)$. Moreover, the adverse effect of LPS on luteal EC networks was dose-dependent and effective from $1 \mathrm{ng} / \mathrm{mL}(P<0.05)$, while few EC networks were present above $10 \mathrm{ng} / \mathrm{mL}$ LPS $(P<0.001)$. LPS reduced proliferation $(P<0.05)$ and increased apoptosis of EC $(P<0.001)$. The specific TLR4 inhibitor TAK242 reversed the effects of LPS on EC networks. In conclusion, luteal vasculature is adversely sensitive to LPS acting via TLR4, therefore ovarian exposure to LPS from any Gramnegative bacterial infection will profoundly influence subsequent reproductive potential.
\end{abstract}

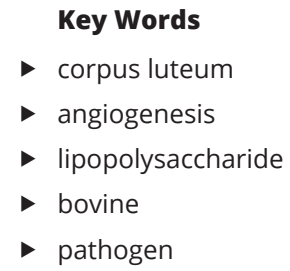

Journal of Endocrinology (2020) 245, 79-92

\section{Introduction}

Parturition is a traumatic event where the endometrium is disrupted and exposed to bacterial contamination. Consequently, uterine bacterial infections are a common consequence of parturition across a number of species, and post-partum uterine disease affects up to $40 \%$ of dairy cattle (Gilbert et al. 2005, Sheldon et al. 2009). Reproductive tract inflammatory disease (RTID) is associated with decreased fertility, manifested as an increased time to 
conception, increased number of inseminations per conception and reduced pregnancy rates (McDougall 2001, Giuliodori et al. 2013). These negative effects result from delayed or abnormal post-partum ovarian cyclicity (Mohammed et al. 2019), reduced dominant follicle growth and function (Sheldon et al. 2002, Williams et al. 2007) or a failure to support early embryo growth including reduced progesterone production (Mateus et al. 2002, Williams et al. 2007). The secretion of progesterone by the corpus luteum (CL) is crucial for pregnancy with even a slight delay in the post-ovulatory rise in progesterone markedly reducing embryonic development and fertility (Mann \& Lamming 2001). Fundamental to luteal development is the intense proliferation of endothelial cells and activation of pericytes which enables the CL to develop rapidly and receive the necessary high blood flow for its critical function (Robinson et al. 2009, Woad \& Robinson 2016).

The bacteria that cause endometritis (persistent uterine inflammation) include Gram-negative (e.g. Escherichia coli) and Gram-positive (e.g. Trueperella pyogenes, Fusobacterium necrophorum and Staphylococcus aureus) organisms (Sheldon et al. 2002, 2009). In the endometrium, these bacteria induce an innate immune response, disrupt endometrial prostaglandin production and cause tissue damage (Gabler et al. 2009, Sheldon et al . 2009, Borges et al. 2012). The effects are not, however, limited to the endometrium, since the cell wall component of Gram-negative bacteria, lipopolysaccharide (LPS), accumulates in follicular fluid to concentrations greater than those detected in peripheral plasma (Mateus et al. 2003), despite bacteria being absent from the ovary itself. Indeed, mean follicular LPS concentrations of $176 \mathrm{ng} / \mathrm{mL}$ are reported in cattle with (sub)clinical endometritis (Herath et al. 2007) demonstrating that LPS released during endometritis reaches and could affect the ovary. Furthermore, there is the potential for specialised vascular transfer of uterine LPS to the ovary, in a manner similar to PGF2a (Knickerbocker et al. 1988, Bonnin et al. 1999). In contrast, less is known about the impact of Grampositive bacteria on ovarian function, although S. aureusinduced mastitis was associated with decreased follicular steroidogenesis (Lavon et al. 2011).

Pathogen-associated molecular patterns (PAMPs) are microbial components that are detected by pattern recognition receptors as part of the innate immune response (Akira et al. 2006). The toll-like receptors (TLR) are integral to the recognition of extracellular or exosomal PAMPs, with TLR2 and TLR4 (Akira et al. 2006) being particularly important with respect to endometritis.
Lipoteichoic acid (LTA) and peptidoglycan (PGN) are cell wall components of Gram-positive bacteria which activate TLR2 signalling, while LPS acts via TLR4 (Akira et al. 2006). Both TLR2 and TLR4 are expressed in granulosa cells and the CL in cattle (Gadsby et al. 2017), with expression localised to both steroidogenic and endothelial cells (Luttgenau et al. 2016). Lipopolysaccharide, LTA and PGN dose-dependently induced an innate immune response in granulosa cells (Price et al. 2013). In contrast, there has been less mechanistic research into the effects of PAMPs on luteal cells in vitro, including luteal endothelial cells.

LPS treatment in vivo reduced luteal blood flow, size and progesterone secretion (Luttgenau et al. 2016), and thus it is feasible that LPS adversely affects luteal function by disrupting the luteal vasculature. Indeed LPS increased apoptosis in bovine (Frey \& Finlay 1998, Ali et al. 2013) and human (Bannerman et al. 1998, Munshi et al. 2002) endothelial cell lines, at a range of treatment doses and durations. Conversely, LPS induced endothelial cell sprouting and angiogenesis in human cell lines (Chen et al. 2009, Shin et al. 2015, Xia et al. 2018). Thus, it is difficult to predict the effect of LPS on ovarian endothelial cells. There is much less known of the effects of TLR2 agonists on endothelial cells, but studies to date indicate that TLR2 agonists promote endothelial cell function (Grote et al. 2010, Saber et al. 2011). However, to the best of our knowledge, there are no reports of the effects of TLR2 agonists on ovarian-derived endothelial cells.

To date, most studies have investigated the negative effects of RTID and bacterial PAMPs on follicular rather than luteal function. The focus of the present study was on the function of the much neglected but equally important CL. Here, we explore the phenotypic characteristics of the CL collected from cows with and without RTID. Based on the profound reduction in luteal vascularity observed in cows with RTID in a preliminary field assessment, mechanistic studies were performed to test the hypothesis that PAMPs would suppress luteal angiogenesis and function in vitro. For the first time, we have revealed that luteal endothelial cells are sensitive to low concentrations of LPS but were unaffected by LTA and PGN; however, progesterone production was unaffected by any PAMPs. Further experiments confirmed that LPS acted on endothelial cells by increasing apoptosis and decreasing proliferation. Moreover, the inhibition of TLR4 negated the profound effects of LPS on luteal endothelial cells, indicating that LPS exerted its action through TLR4. Collectively, these experiments are a major expansion of our knowledge of PAMPs and their effects on endothelial cells derived from the ovary. 


\section{Materials and methods}

\section{Tissue collection}

To assess the impact of reproductive tract inflammatory disease (RTID) on luteal structure and function, bovine reproductive tracts were collected at abattoir. Uteri had undergone involution post-partum and attained nonpregnant size. Mature CL (day 8-16; Ireland et al. 1980) were isolated from cows with $(n=3)$ and without $(n=3)$ RTID, which was determined by visual inspection and subsequently confirmed by histological analysis of a uterine cross section (Fig. 1). CL were divided and quarters were either (1) fixed in Bouin's solution for $6 \mathrm{~h}$ prior to processing to paraffin blocks, (2) stored at $-80^{\circ} \mathrm{C}$ for protein extraction or (3) homogenised for tissue progesterone content.

To determine the impact of PAMPs on luteal cells in culture, bovine ovaries were collected at abattoir and early CL (days 1-4; Ireland et al. 1980) were selected and dissected.

\section{Cell culture}

Luteal cells (including steroidogenic, endothelial, pericytes and fibroblasts) from early CL $(n=3-6$
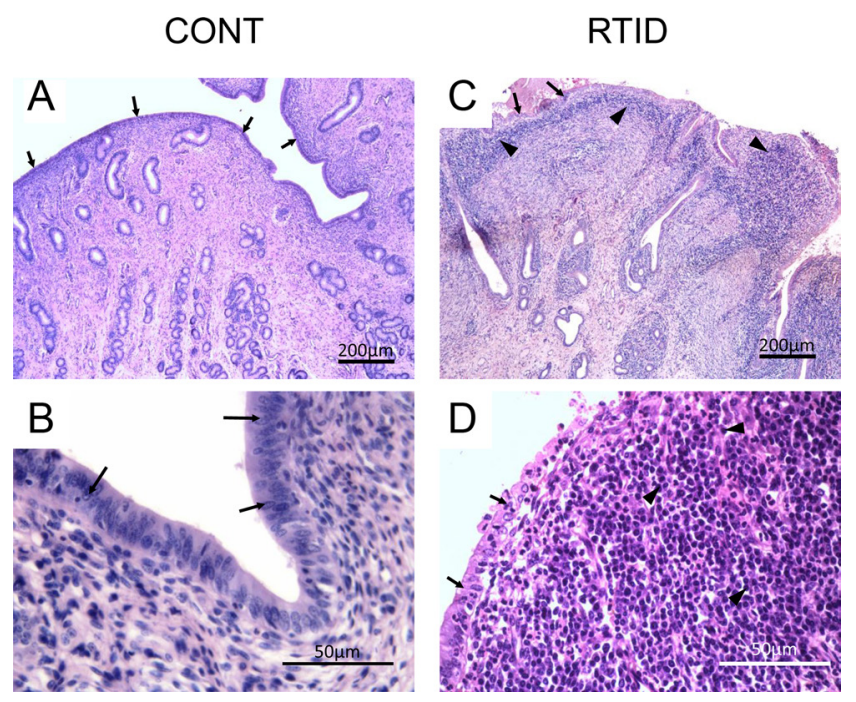

\section{Figure 1}

Reproductive tract inflammatory disease is associated with immune cell infiltration into the endometrium and disruption to the luminal epithelium. Histological analysis of the uterus from control cows (CONT; $A, B)$ and cows with reproductive tract inflammatory disease (RTID; C, D). In cows with RTID, there was some disruption to the luminal epithelium (arrows), while the luminal epithelium was intact in the control cows. Importantly, there was extensive infiltration of immune cells (arrowheads) in the sub-epithelial layer. Images in B and D are under higher magnification (40x) and the scale bars are 50-200 $\mu \mathrm{m}$. A full colour version of this figure is available at https://doi.org/10.1530/JOE-19-0443. per experiment, see figure legends for details) were enzymatically dispersed with $2 \mathrm{mg} / \mathrm{mL}$ collagenase I type 1A (Sigma-Aldrich Company Ltd.) and $25 \mu \mathrm{g} / \mathrm{mL}$ DNase I (Sigma-Aldrich) in DMEM/Ham's F12 media for $2 \times 45$ min at $37^{\circ} \mathrm{C}$, as previously described (Robinson et al. 2008, Woad et al. 2012). Dispersed cells were filtered (70 $\mu \mathrm{m})$ and washed thrice in supplemented EBM-2 (Lonza, Basel, Switzerland; (Robinson et al. 2008, Woad et al. 2012)). Cells were plated onto fibronectin-coated coverslips at $2 \times 10^{5}$ viable cells/well in a 12 -well plate, and incubated at $39^{\circ} \mathrm{C}$ with $5 \% \mathrm{CO}_{2}$.

Spent culture medium was collected and replaced with fresh supplemented EBM-2 after $24 \mathrm{~h}$ and thereafter every 2 days. From culture day 1, cells were treated with or without ultrapure E. coli lipopolysaccharide (LPS, TLR4 agonist), S. aureus lipoteichoic acid (LTA, TLR2 agonist) or B. subtillis peptidoglycan (PGN, TLR2 agonist) for 5 days (InvivoGen, Toulouse, France; concentrations as detailed in figure legends). Cells were further treated with or without $1 \mu \mathrm{M}$ TAK242 (TLR4 signalling inhibitor; InvivoGen). All cultures were performed in the presence of FGF2 and VEGFA. When the cells were fully confluent they were either (1) fixed in acetone:methanol $(1: 1)$ at $4^{\circ} \mathrm{C}$ for 10 min prior to immunostaining or (2) collected for protein extraction.

\section{Progesterone analysis}

To quantify progesterone content of luteal tissue, CL were homogenised in ice-cold PBS and progesterone extracted with petroleum ether (Tsang et al. 1990). Samples were diluted 1:800 in PBS prior to analysis by progesterone ELISA (Ridgeway Science; Gloucestershire, UK: RRID:AB_2801662), with an intra-assay coefficient of variation $(\mathrm{CV})$ of $5.6 \%$.

To quantify progesterone concentration in spent culture media, samples were diluted with PBS (1:50-1:500) as appropriate and measured by the same ELISA. The lower limit of sensitivity was $0.2 \mathrm{ng} / \mathrm{mL}$, with an intra- and inter-assay CV of $6.9 \%$ and $10.5 \%$, respectively.

\section{Protein extraction}

Luteal tissue (100 $\mathrm{mg}$ ) was homogenised on ice in $2 \mathrm{~mL}$ of ice-cold lysis buffer $(0.1 \mathrm{M}$ Tris $\mathrm{pH} 7.4,1 \mathrm{mg} / \mathrm{mL}$ dithiothreitol, $1 \mathrm{mg} / \mathrm{mL}$ SDS, $0.18 \mathrm{mg} / \mathrm{mL}$ sodium orthovanadate with protease inhibitor cocktail (SigmaAldrich)). Cultured luteal cells were lysed in $50 \mu \mathrm{l}$ of icecold cell extraction buffer (FNN0011, Thermo Scientific) 
supplemented with protease inhibitor cocktail (SigmaAldrich) and rapidly freeze-thawed five times. Both tissue and cell lysates were then sonicated and centrifuged at $13,000 \mathrm{~g}$ for $15 \mathrm{~min}$. Protein concentrations were determined by Bradford Protein assay (Bio-Rad Laboratories Ltd.).

\section{Western blotting}

Relative protein expression in luteal tissue or luteal cells following LPS treatment was determined by Western blot analysis. The primary antibodies used were rabbit polyclonal anti-human CYP11A (Abcam; RRID:AB_1310110 (Fadhillah et al. 2014)), HSD3B (a gift of Dr Richard Parker, University of Birmingham, AL, USA (Robinson et al. 2006)), STAR (Abcam; RRID:AB_10678397 (Fadhillah et al. 2014)) and mouse monoclonal anti-human ACTA2 (Sigma-Aldrich; RRID:AB_476701 (Robinson et al. 2006)). Blots were divided to enable multiple probing with different antibodies. Protein bands were quantified by densitometry (ImageJ; NIH, Bethesda, MD, USA (Schneider et al. 2012)) and normalised to Histone H3 loading control (Abcam; RRID:AB_302613). Preliminary experiments determined the presence of a single band of the appropriate size for all proteins of interest, except CYP11A. In this case a second non-specific band was observed at $20 \mathrm{kDa}$; however, this was neither contained in the final excised region nor quantified.

\section{Histological analysis and immunostaining}

Five-micrometre sections of uterus and CL were dewaxed with histoclear and rehydrated through graded alcohols. Uterine sections were stained with haematoxylin and eosin for histological confirmation of immune cell infiltration into the endometrium and some disruption to the luminal epithelium (Bondurant 1999).

For luteal tissue sections and luteal cells grown on coverslips, endothelial cells were localized with von Willebrand Factor (VWF), while perivascular pericytes were localized with smooth muscle actin (ACTA2) immunostaining (Robinson et al. 2006). Primary antibodies were rabbit polyclonal anti-human VWF (20 $\mathrm{\mu g} / \mathrm{mL}$; Dako/Agilent; RRID:AB_2315602) or mouse monoclonal anti-human ACTA2 (5 $\mu \mathrm{g} / \mathrm{mL}$; Sigma-Aldrich; RRID:AB_476701). For negative control slides, primary antibodies were replaced with equivalent concentrations of rabbit or mouse IgG.

For luteal tissue sections, antigen retrieval was additionally performed by incubating with either
$0.4 \mathrm{mg} / \mathrm{mL}$ trypsin, $0.25 \mathrm{mg} / \mathrm{mL} \mathrm{CaCl}_{2}$ in $\mathrm{PBS}$ at room temperature (RT) for $15 \mathrm{~min}$ (for VWF) or boiling in $10 \mathrm{mM}$ sodium citrate buffer $(\mathrm{pH} 6$ ) for $10 \mathrm{~min}$ (for ACTA2) Endogenous peroxidase activity was quenched with $0.3 \%(\mathrm{v} / \mathrm{v})$ hydrogen peroxide in methanol for $5 \mathrm{~min}$ at RT. After two washes in PBS, $20 \%$ normal goat serum (for VWF) or 4\% normal horse serum (for ACTA2) was applied for $30 \mathrm{~min}$ at RT. Primary antibodies were then incubated overnight at $4^{\circ} \mathrm{C}$.

Sections/coverslips were washed in PBS and incubated with biotinylated anti-rabbit IgG (Vector Laboratories Ltd., Peterborough, UK) or biotinylated horse antimouse IgG (Vector Laboratories) for $30 \mathrm{~min}$ at RT. This was followed by PBS washes and then incubation with $\mathrm{ABC}$ (Vector Laboratories) for $30 \mathrm{~min}$ at RT. After washing, diaminobenzidine (Vector Laboratories) was applied for 1-5 min, then washed and counterstained with haematoxylin before dehydration through graded alcohols. Tissue sections were mounted using Permount (Fisher Scientific, Loughborough, UK), while the cell culture coverslips were removed from each culture well and further dehydrated in xylene before mounting onto a glass slide with DPX mountant (Sigma-Aldrich).

\section{Dual label immunofluorescence}

To determine endothelial cell proliferation, coverslips were simultaneously incubated with mouse antihuman Ki67 (diluted 1:100, Vector Laboratories; RRID:AB_2314697 (Robinson et al. 2006)) and $20 \mu \mathrm{g} / \mathrm{mL}$ biotinylated Griffonia (Bandeiraea) simplicifolia isolectin B4 (Vector Laboratories; RRID:AB_2314661 (Plendl et al. 1996)) in a humidified chamber at $4^{\circ} \mathrm{C}$ overnight. Targets were localised following incubation with TexasRed conjugated anti-mouse IgG $(20 \mu \mathrm{g} / \mathrm{mL}$; Vector Laboratories) and fluorescein-labelled avidin DCS (20 $\mu \mathrm{g} / \mathrm{mL}$; Vector Laboratories) for $1 \mathrm{~h}$ at RT.

To determine endothelial cell apoptosis, coverslips were simultaneously incubated with rabbit antihuman cleaved caspase-3 (diluted 1:300, Cell Signaling Technology; RRID:AB_10897512 (Zielniok etal. 2014)) and $20 \mu \mathrm{g} / \mathrm{mL}$ biotinylated Griffonia (Bandeiraea) simplicifolia isolectin B4 (Vector Laboratories; RRID:AB_2314661) in a humidified chamber at $4^{\circ} \mathrm{C}$ overnight. Targets were localised following incubation with Alexa Fluor 594 conjugated anti-rabbit IgG (10 $\mathrm{\mu g} / \mathrm{mL}$; Thermo Fisher) and fluorescein-labelled avidin DCS $(20 \mu \mathrm{g} / \mathrm{mL}$; Vector Laboratories). All coverslips were washed twice with PBS and mounted in Vectashield with DAPI (Vector Laboratories). 


\section{Results}

All image analysis was performed using Image Pro-Plus 6.0 (Media Cybernetics, Wokingham, UK). The quantification of VWF or ACTA2 immunostaining of luteal tissue was as previously described (Robinson et al. 2006), with two sections selected for each CL sample. For each section, ten fields of view were randomly captured under $20 \times$ objective using Leica DM4000B microscope (Leica Microsystem (UK), Ltd, Milton Keynes, UK), equipped with a QImaging micropublisher 5.0 RTV colour camera (QImaging (UK) Ltd, St Helens, UK) and the area of positive staining was determined. The formation of endothelial cell (EC) networks in culture was analysed (Robinson et al. 2008, Woad et al. 2012) by capturing 12 images of VWF immunostaining per coverslip under a $5 \times$ objective. The total area of EC networks, number of branch points and the extent of branching was determined. For each coverslip, the data were expressed as either percentage relative to control for that particular culture or the actual value recorded as indicated.

To estimate apoptotic and proliferation indices by dual labelling, five non-overlapping images of each coverslip were captured under the $40 \times$ objective lens using a Leica DM5000B fluorescence microscope, equipped with a Leica DFC350fx camera (Leica Microsystem (UK), Ltd). Only endothelial cells (isolectin positive) with nuclear caspase-3 (green) or Ki67 (red) staining were counted. The total number of DAPI stained endothelial cell nuclei was then counted and indices calculated.

\section{Statistical analyses}

Statistical analyses were performed in Genstat 19.0 (VSN International, Hemel Hempstead, UK). All data were checked for normality using residual plots and homogeneity of variance by Bartlett's test. Data were $\log$ transformed where appropriate. Differences were considered significant at $P<0.05$ and results are presented as mean and associated s.E.M. The effect of RTID on luteal weight, percentage area of staining (VWF, ACTA2), progesterone content and relative protein expression were analysed by t-test.

The effects of PAMPs on luteal cells in culture were determined by randomised block ANOVA, with treatment as factor and blocked by culture, followed by Tukey's multiple comparisons test. The number of independent pools of luteal cells per experiment is indicated in the figure legends.

\section{Reproductive tract inflammatory disease is associated with reduced luteal progesterone content and steroidogenic capacity}

In the control cows, all uterine layers appeared histologically normal, with an intact luminal epithelium, extensive gland formation and minimal infiltration of immune cells (Fig. 1A and B). In contrast, in cows with RTID, there was some disruption to the luminal epithelium, extensive infiltration of immune cells into the sub-epithelial layer and dilatation of the blood vessels (Fig. 1C and D). All control and RTID cows had an apparently active CL present at the time of tissue collection, without signs of regression.

Corpora lutea from cows with confirmed RTID were 1.2-fold smaller than those from control cows $(P<0.05$; Table 1). Similarly, luteal progesterone content (1.2-fold; $P<0.05)$ and total luteal progesterone content $(1.5$-fold; $P<0.05)$ were reduced in cows with RTID compared to control cows (Table 1).

Reproductive tract inflammatory disease was associated with a significant reduction in luteal steroidogenic protein expression (Fig. 2). Luteal CYP11A protein expression was reduced by 1.5 -fold $(P<0.05)$, HSD3B by 4.6 -fold $(P<0.01)$ and STAR by 1.6 -fold $(P<0.01)$ in the presence of RTID vs controls.

\section{Reproductive tract inflammatory disease is associated with reduced luteal vascularity}

An extensive microvasculature was observed in CL of control cows in the mid-luteal phase, such that the majority of steroidogenic cells were in close proximity to endothelial cells (Fig. 3A). In contrast, the vascularity appeared markedly reduced in cows with RTID, with a limited localisation of endothelial cells (Fig. 3B) and

Table 1 Reproductive tract inflammatory disease (RTID) is associated with reduced luteal weight and progesterone content.

\begin{tabular}{|c|c|c|c|}
\hline & Control $(n=3)$ & $\mathbf{R T I D}(n=3)$ & $P$ value \\
\hline CL weight (g) & $4.17 \pm 0.18$ & $3.47 \pm 0.15$ & 0.04 \\
\hline $\begin{array}{l}\text { Luteal } \\
\text { progesterone } \\
\text { content (ng/mg) }\end{array}$ & $1827 \pm 45$ & $1493 \pm 88$ & 0.03 \\
\hline $\begin{array}{l}\text { Total luteal } \\
\text { progesterone }(\mu \mathrm{g})\end{array}$ & $7625 \pm 497$ & $5186 \pm 443$ & 0.02 \\
\hline
\end{tabular}


B
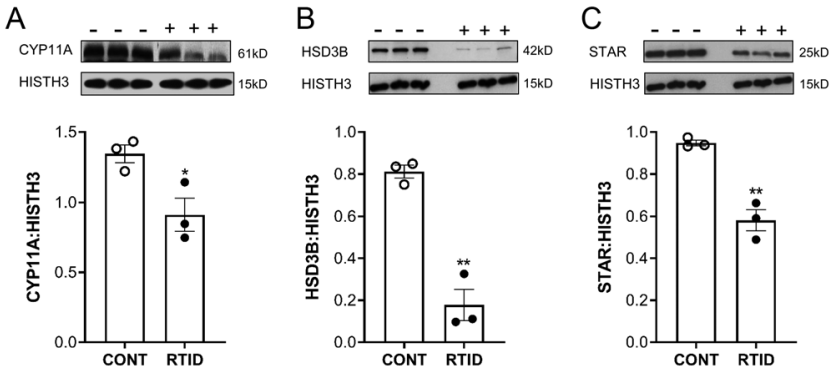

Figure 2

Reproductive tract inflammatory disease is associated with reduced luteal steroidogenic protein expression. Protein expression of CYP11A (A), HSD3B (B) and STAR (C) was quantified and normalised to HISTH3. Significant reductions in luteal CYP11A, HSD3B and STAR expression were observed in cows with reproductive tract inflammatory disease (RTID; +; $n=3$ ) vs control (CONT; $-; n=3) ; * p<0.05 ; * * p<0.01$. Data are mean \pm S.E.M.

large areas of parenchyma devoid of endothelial cells. Quantification of VWF staining revealed a 3.7-fold reduction in the degree of luteal vascularisation in cows with RTID vs controls $(P<0.05$, Fig. 3C).

In the $\mathrm{CL}$ of control cows, there was considerable localisation of pericytes (ACTA2-positive cells) throughout the luteal parenchyma. The expression pattern across the luteal section was similar to that for VWF and ACTA2-staining was particularly evident in larger capillaries (Fig. 3D). In cows with RTID, there was a 3.5-fold reduction in luteal pericyte coverage $(P<0.001$; Fig. 3E and F). Western blot analysis of normalised luteal ACTA2 expression revealed an 8-fold reduction in ACTA2 expression in cows with RTID $(1.67 \pm 0.02$ vs $0.21 \pm 0.05$, $P<0.001$ ) (data not shown).

\section{Luteal endothelial cell network formation is dramatically reduced by treatment with lipopolysaccharide, but not lipoteichoic acid or peptidoglycan}

Cells from early corpora lutea were challenged with a range of PAMPs, to determine their impact on endothelial cell (EC) network formation and progesterone production. Luteal cells were cultured in the presence and absence of ultrapure LTA, PGN or LPS for 5 days, at two different concentrations as recommended by the manufacturer (InvivoGen, Toulouse, France) and previously reported (Bromfield \& Sheldon 2011).

In the control wells, the cells reached confluence with extensive formation of EC into highly-organised networks. These EC networks had multiple complex branch points and were present across the whole coverslip. Treatment with LTA or PGN at either dose did not affect
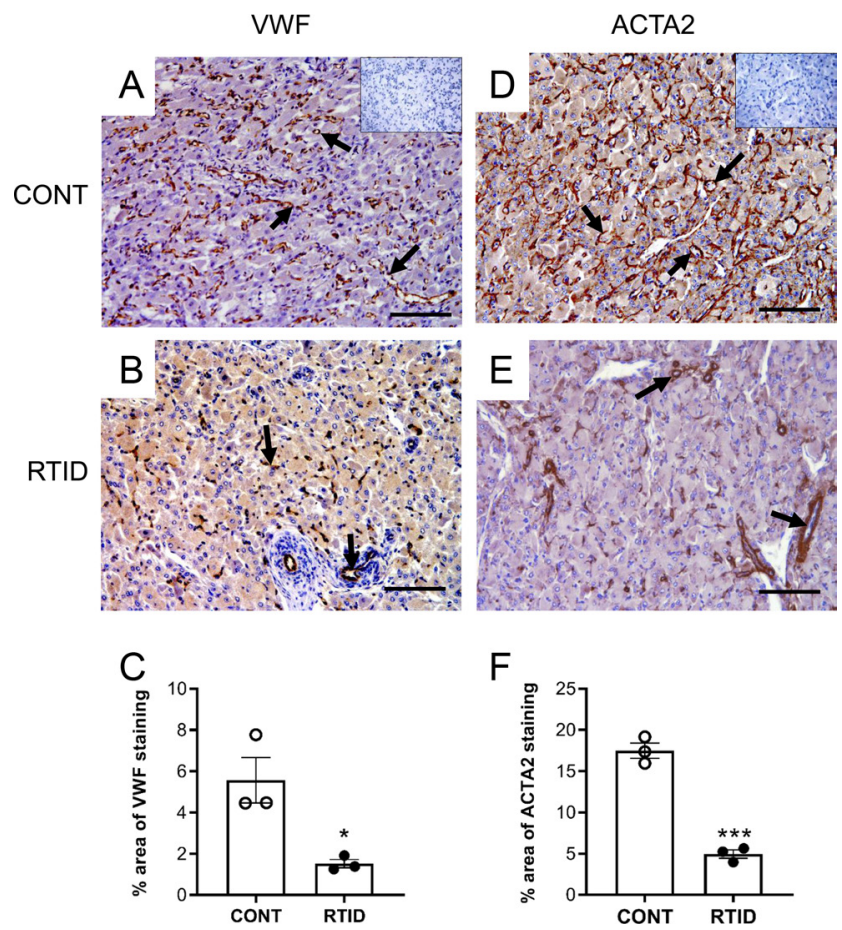

Figure 3

Reproductive tract inflammatory disease is associated with reduced luteal vascularity. Immunohistochemical localisation of von Willebrand factor (VWF; A, B), and smooth muscle actin (ACTA2; D, E) in bovine corpora lutea. The VWF and ACTA2 staining (black arrows) were more extensive in control cows (CONT; A, D) compared to those with reproductive tract inflammatory disease (RTID; $B, E)$. Significant reductions in percentage area of VWF (C) and ACTA2 (F) staining were observed in cows with RTID vs control ( $* P<0.05 ; * \star \star P<0.001)$. Data are mean \pm S.E.M. from three control and three RTID cows. Scale bars represent $100 \mu \mathrm{m}$. Negative controls (inset $A$ and $D$ ) following replacement of each primary antibody with equivalent concentrations of IgG. A full colour version of this figure is available at https://doi.org/10.1530/JOE-19-0443.

any endothelial cell growth parameters analysed $(P>0.05$; Fig. 4). In contrast, the presence of LPS visibly reduced the number and extent of EC networks (Fig. 4), while appearing not to affect the overall degree of confluency. Image analysis (Fig. 4) confirmed that LPS treatment markedly reduced the total area of EC networks at both low $(P<0.05)$ and high $(P<0.001)$ concentrations. Indeed, at the highest dose of LPS, the total area of EC networks was reduced by nearly 20 fold. Similarly, the total number of branch points was reduced by low $(P<0.05)$ and high $(P<0.001)$ concentrations of LPS. Conversely, the degree of branching within a network was only affected by the high dose of LPS $(P<0.05)$.

In the control wells, luteal cell progesterone production increased with time in culture, with progesterone concentrations increasing nearly 3 -fold between day 3 and 5 of culture $(P<0.001)$. The progesterone production by luteal cells was, however, unaffected by incubation 

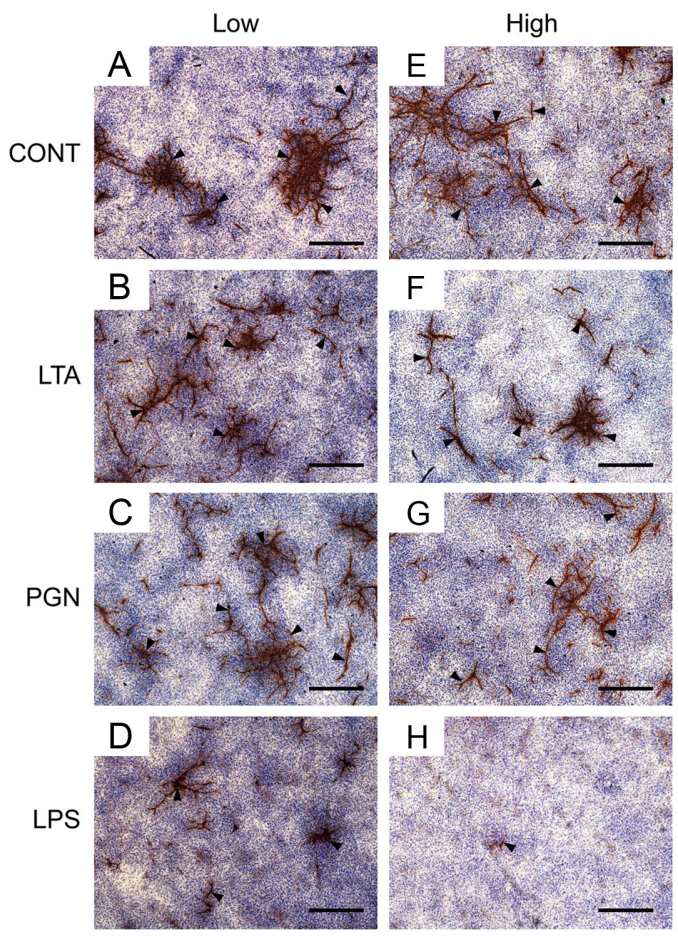

with LTA, PGN or LPS at any concentration, on either day 3 or 5 of culture $(P>0.05$, Fig. 5$)$.

\section{The lipopolysaccharide-induced reduction in luteal endothelial cell network formation is reversed by inhibition of toll-like receptor 4 signalling}

Endothelial cell network formation was dramatically and dose-dependently reduced by LPS at concentrations from 1-1000 ng/mL (Fig. 6). Indeed, the total EC network area was reduced by $25 \%$ at $1 \mathrm{ng} / \mathrm{mL}$ LPS $(P<0.05)$. In the presence of LPS at $10 \mathrm{ng} / \mathrm{mL}$ and above, only very sparse growth of endothelial cells was observed $(P<0.01)$. In the control cells, TAK242 treatment reduced the total EC network area by $25 \%(P<0.01)$ but did not affect the number of branch points $(P>0.05)$ and degree of branching $(P>0.05)$. The addition of TAK242 treatment to LPS-treated luteal cells restored all EC network formation parameters to control levels ( $P<0.001$ vs LPS treatment).

\section{Lipopolysaccharide reduces proliferation and increases apoptosis of endothelial cells}

To determine how LPS might act to adversely affect EC numbers, proliferation and apoptosis indices were calculated following LPS exposure. In this experiment, the cells were fixed on day 5 prior to confluency, to better enable identification of ongoing cell dynamics.
In agreement with our previous study (Woad et al. 2012), in the control wells, the EC were observed in large clusters of tightly packed cells with less apparent branching (Fig. 7A). Treatment with LPS reduced total EC area $(P<0.05)$ and number of branch points $(P<0.05)$ in a dose-dependent manner (Fig. 7E and F).

Minimal apoptosis was observed in the absence of LPS (Fig. 7C); however, LPS treatment dose-dependently increased luteal EC apoptosis $(P<0.001)$, with a maximal apoptotic index of $45 \%$ (Fig. 7G). Luteal cells (including endothelial cells) had proliferated in culture in the absence of LPS (Fig. 7D), with an observed EC-specific proliferation index of $24 \%$. LPS exposure at $1000 \mathrm{ng} / \mathrm{mL}$ significantly reduced EC proliferation by 1.4 -fold $(P<0.05)$ with intermediate proliferation observed at $10 \mathrm{ng} / \mathrm{mL}$ LPS (Fig. 7H).

\section{Lipopolysaccharide does not alter progesterone production or steroidogenic protein expression in vitro}

In the control wells, luteal cell progesterone production increased with time in culture, with progesterone concentrations increasing nearly 2.6-fold between day 3 and 5 of culture. In agreement with the previous experiment, progesterone production by luteal cells was unaffected by incubation with LPS at both concentrations, on either day 3 or 5 of culture ( $P>0.05$, Fig. $8 \mathrm{~A}$ and B). 
A
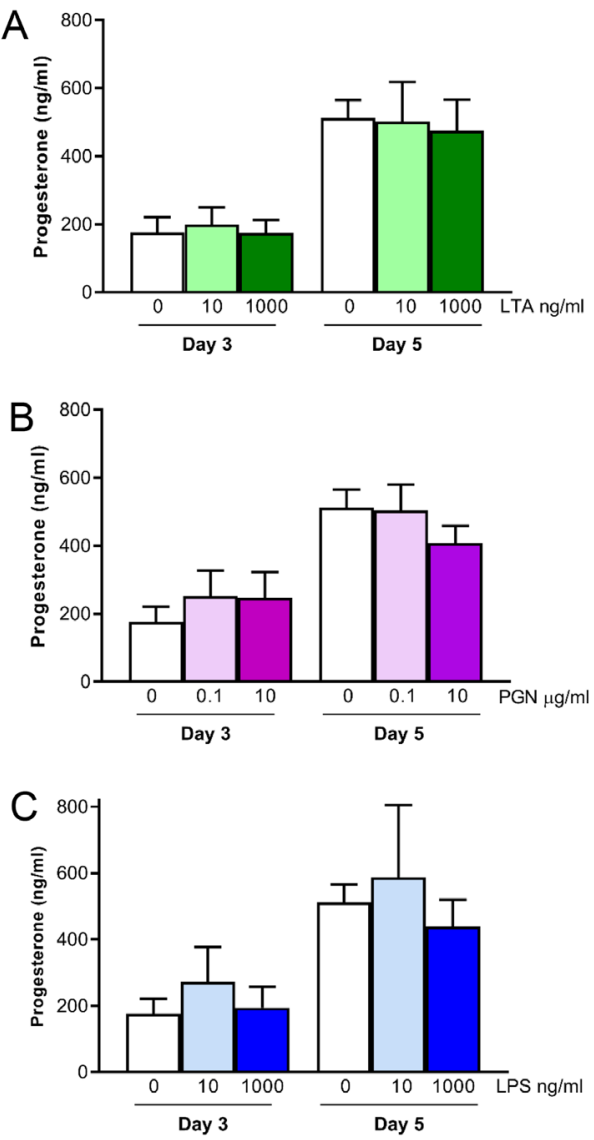

\section{Figure 5}

Luteal progesterone production in vitro was unaffected by treatment with microbial components. Luteal cells were cultured for 5 days in the absence or presence of lipoteichoic acid (LTA; A), peptidoglycan (PGN; B) or lipopolysaccharide (LPS; C) and the progesterone concentration of spent media was measured by ELISA on days 3 and 5. Progesterone production increased with time in culture $(P<0.001)$ but was unaffected by treatment. Data are mean + S.E.M. from three independent cultures. A full colour version of this figure is available at https://doi.org/10.1530/ JOE-19-0443.

Similarly, the expression of CYP11A, HSD3B and STAR protein on day 5 of culture was unaffected by LPS treatment $(P>0.05$, Fig. $8 C, D$ and $\mathrm{E})$.

\section{Discussion}

This study demonstrates that RTID is associated with adverse alterations in both luteal structure and function. Total luteal P4 content was reduced 1.5 -fold in cows with RTID vs control cows, reflecting diminished luteal CYP11A, STAR and HSD3B protein expression. Indeed, these observations occurred during a period when luteal structure and function are stable (days 8-16) with respect to weight, steroidogenic enzyme expression and activity
(Couet et al. 1990, Pescador et al. 1996, Mann 2009). In addition, luteal vascularity was dramatically reduced, as judged by both endothelial and perivascular cell coverage, and would be expected to further contribute to a critical functional insufficiency and decreased likelihood of achieving a pregnancy.

This extends previous findings, whereby repeated intrauterine LPS infusions resulted in decreased plasma P4 concentrations (Williams et al. 2008, Luttgenau et al. 2016) and steroidogenic factor mRNA expression was reduced following in vivo LPS challenge (Herzog et al. 2012, Luttgenau et al. 2016). Similarly, high levels of uterine pathogens were associated with reduced plasma progesterone concentrations (Williams et al. 2007). Notably, the presence of RTID has not prevented final follicular growth or ovulation, but has attenuated the resulting CL, both structurally and functionally.

Luteal blood flow was transiently suppressed following LPS challenge in cows (Herzog et al. 2012). This lowered luteal perfusion was predicted to be the result of systemic alterations and increased vascular permeability (Herzog et al. 2012). The present study suggests for the first time that LPS associated with RTID also induces deleterious luteal microvascular changes.

Using a physiologically relevant mixed luteal cell culture (Robinson et al. 2008, Woad et al. 2012), we have demonstrated that LPS adversely affects endothelial cell network formation, with a dramatic $95 \%$ loss of EC cells observed in response to the highest concentration $(1 \mu \mathrm{g} / \mathrm{mL})$, which is similar to the upper range of LPS detected in the follicular fluid of cows with clinical endometritis (mean $176 \mathrm{ng} / \mathrm{mL}$, range 4.3-875.2 ng/mL; (Herath et al. 2007)). Furthermore, total endothelial network area was sensitive to even low concentrations of LPS $(1 \mathrm{ng} / \mathrm{mL})$. In contrast, alternative pathogenassociated molecules LTA and PGN had no impact on angiogenesis vs controls at any concentration.

LPS has been shown to promote angiogenesis in a range of settings; stimulating endothelial cell proliferation, migration and microvessel sprouting (Chen et al. 2009, Shin et al. 2015, Xia et al. 2018) resulting in potential pro-angiogenic clinical applications (Ma et al. 2017). In contrast, deleterious effects of LPS on cultured endothelial cells have also been observed, resulting in endothelial dysfunction and cell death (Bannerman et al. 1998, Frey \& Finlay 1998, Munshi et al. 2002, Ali et al. 2013). On the other hand, TLR2-ligands have been shown to promote angiogenesis, significantly increasing endothelial cell proliferation, tube formation and migration both in vivo and in vitro (Grote et al. 2010, Saber et al. 2011). 

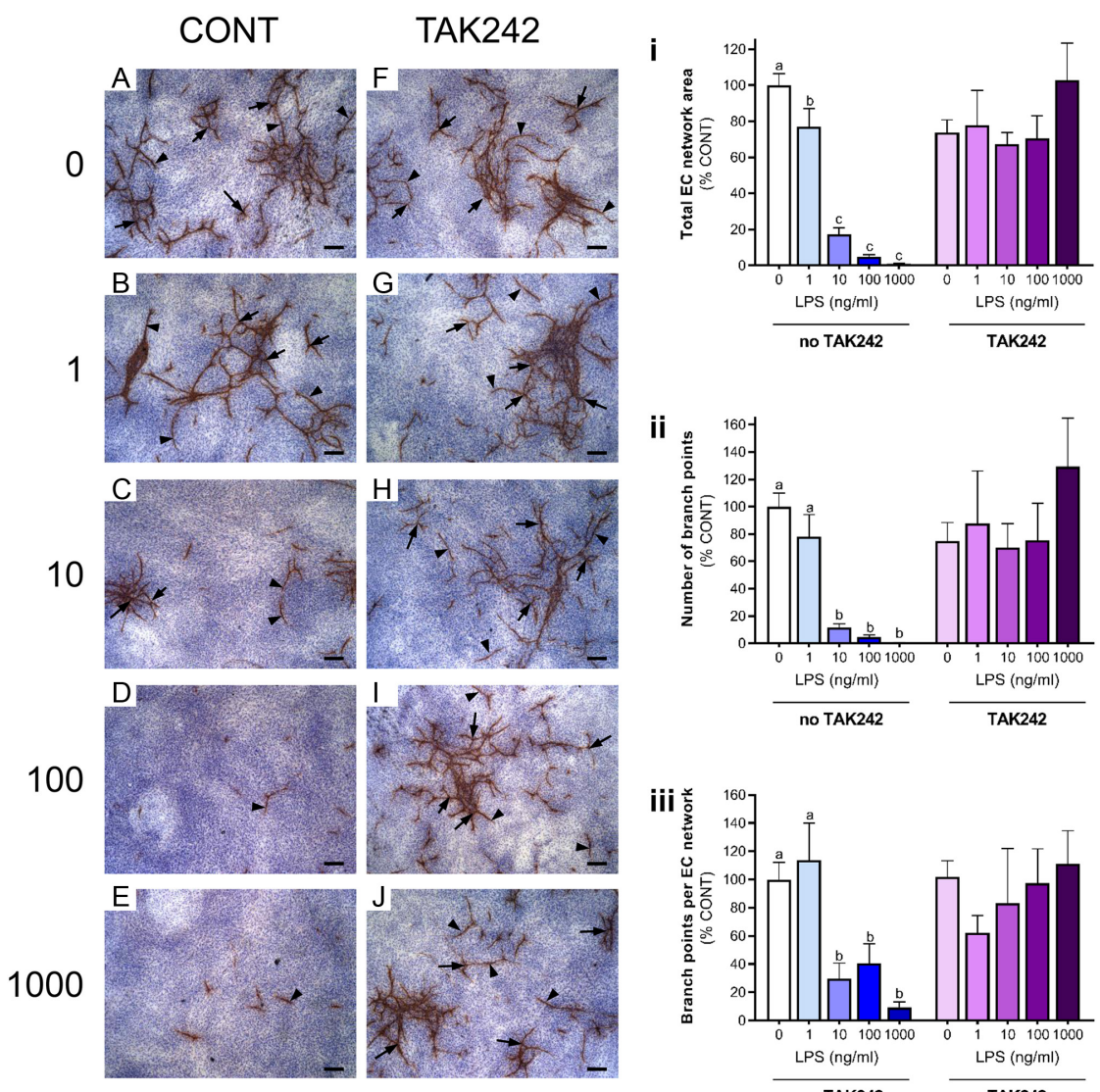

\section{Figure 6}

Toll-like receptor 4 signalling blockade reversed the lipopolysaccharide-induced decrease in endothelial cell network formation in vitro. Luteal cells were cultured for 7 days in the absence $(A, F)$ or presence (B, C, D, E, G, H, I and J) of

lipopolysaccharide (LPS), without (A, B, C, D and E) or with ( $F, G, H, I$ and J) $1 \mu$ M TAK242

co-incubation to inhibit toll-like receptor (TLR)4 signalling. Endothelial cell (EC) networks (brown, arrowheads) were identified by von Willebrand Factor immunocytochemistry. The branch points

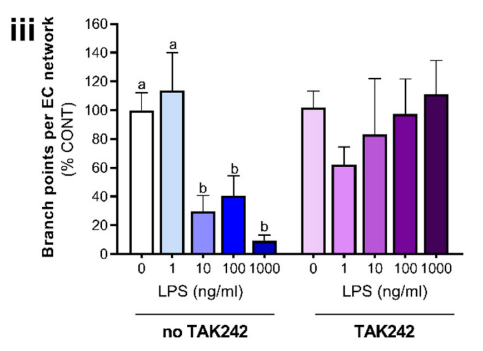
are indicated by arrows. Scale bars represent 200 $\mu \mathrm{m}$. Total EC network area (i), number of branch points (ii) and branch points per network (iii) were quantified. LPS significantly reduced EC network parameters and this was reversed in the presence of TAK242. Data are mean+s.E.M. from 4 to 6 independent cultures. Significance $(P<0.05)$ between groups is indicated by different letters $a>b>c$. A full colour version of this figure is available at https://doi.org/10.1530/JOE-19-0443.
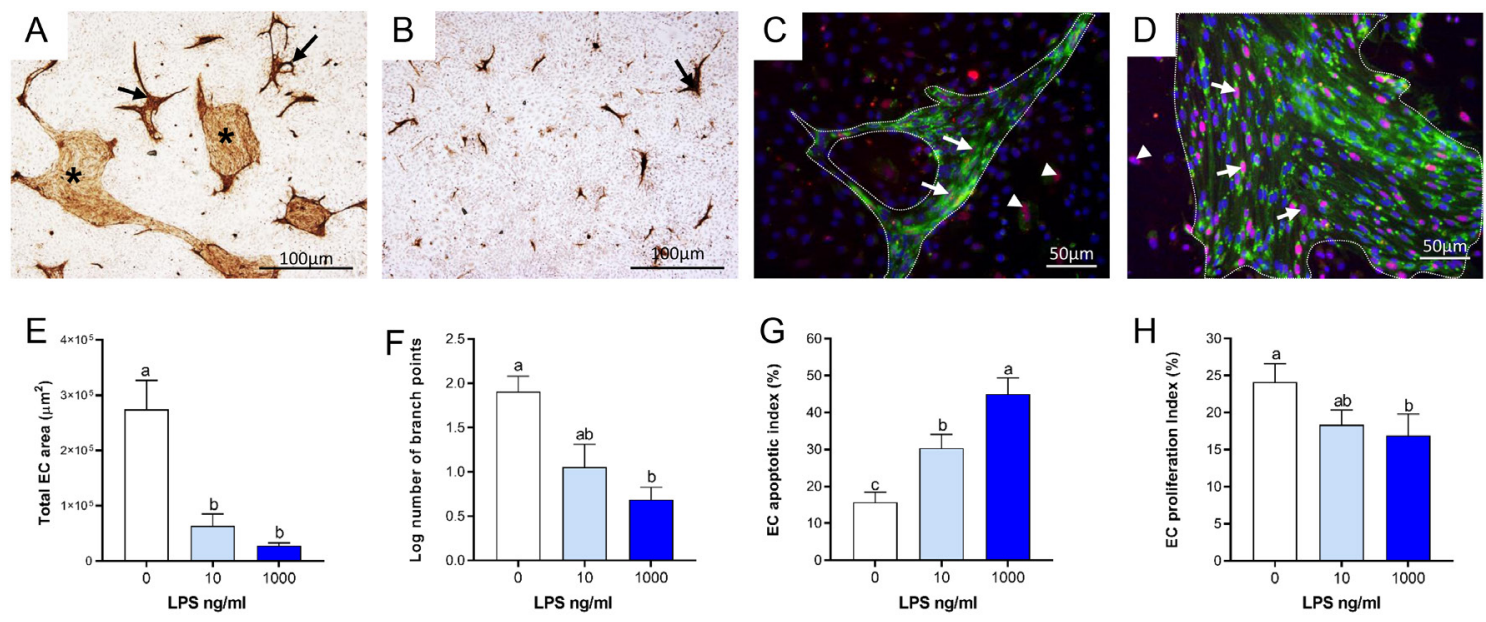

\section{Figure 7}

Lipopolysaccharide reduced endothelial cell area, acting via increased apoptosis and reduced proliferation. Luteal cells were cultured for 5 days in the absence (A, C and D) or presence (B) of $1000 \mathrm{ng} / \mathrm{mL}$ lipopolysaccharide (LPS). Large clusters of endothelial cells (EC, black asterisks and white dotted lines) with signs of branching and network formation occurring (black arrows) were identified by von Willebrand Factor immunocytochemistry (brown; A, B) or isolectin staining (green; C, D). Total EC area (E) and number of branch points (F) were quantified. Overlay images of endothelial-specific expression of activated caspase-3 (pink; C) and Ki67 (pink; D) were quantified and presented as apoptotic (G) and proliferation (H) indices. Apoptotic and proliferating EC are labelled with white arrows, while white arrowheads indicate apoptotic and proliferating non-endothelial cells. Nuclear counterstain, DAPI, blue. Data are mean + S.E.M. from three independent cultures. Significance $(P<0.05)$ between groups is indicated by different letters $a>b>c$. A full colour version of this figure is available at https://doi.org/10.1530/JOE-19-0443. 
A

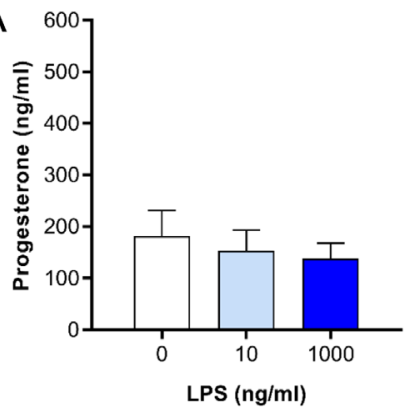

B

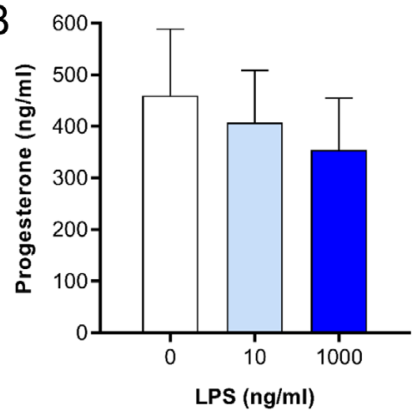

C
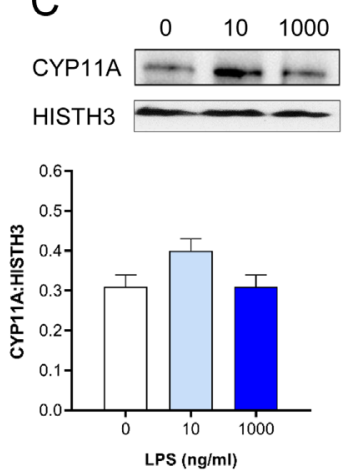

D
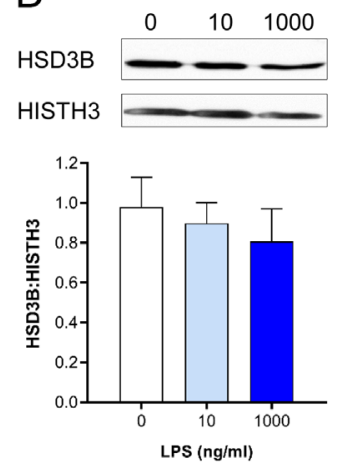

$E$
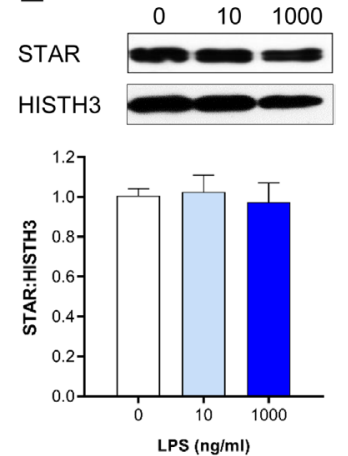

\section{Figure 8}

Lipopolysaccharide does not alter progesterone production or steroidogenic protein expression in vitro. Luteal cells were cultured for 5 days in the absence or presence of lipopolysaccharide (LPS) and the progesterone concentration of spent media was measured by ELISA on days $3(A)$ and 5 (B). Protein expression of CYP11A (C), HSD3B (D) and STAR (E) was quantified and normalised to HISTH3. Data are mean + S.E.M. from three independent cultures. A full colour version of this figure is available at https://doi.org/10.1530/ JOE-19-0443.
Notably, the LPS-induced inhibition of angiogenesis occurred despite the presence of the predominant stimulators of angiogenesis, FGF2 and VEGFA (Robinson et al. 2008, Woad et al. 2012). Both FGF2 and VEGFA were exogenously supplemented in culture, in addition to any potential endogenous production. Indeed, significant in vitro VEGFA production was previously observed in a related luteinising follicular angiogenesis system (Nwachukwu 2019). VEGFA is a known endothelial survival factor, with potent anti-apoptotic activity (Alon et al. 1995, Ferrara et al. 2003). Furthermore, pre-treatment of human umbilical vein endothelial cells with VEGFA was protective against LPS-induced apoptosis (Munshi et al. 2002), although the degree of protection conferred by VEGFA decreased at higher concentrations of LPS $(1 \mu \mathrm{g} / \mathrm{mL})$.

Toll-like receptors are critical for microbial detection and host defence (Akira et al. 2006), and while TLRs are predominantly expressed by immune cells, they have been localised to the reproductive tract, including normal and malignant human ovaries and ovarian tumour cells (Zhou et al. 2009, Zuo et al. 2017). Cumulus oocyte complexes of ovulating follicles express a range of immune-related genes including TLR4 (Hernandez-Gonzalez et al. 2006, Shimada et al. 2006). Bovine granulosa cells of developing follicles express mRNA encoding TLR4 and its co-receptors CD14 and MD-2 (Herath et al. 2007). Furthermore, bovine corpora lutea express TLR2 and TLR4 mRNA
(Nicholls et al. 2016, Gadsby et al. 2017), and TLR2 and 4 immunoreactivity was localised to luteal endothelial and steroidogenic cells (Luttgenau et al. 2016). The presence of critical TLR signalling components is also supported by the observation that bovine granulosa cells initiate an inflammatory response to pathogen-associated molecular patterns including LPS, while oocyte maturation is perturbed in response to LPS (Bromfield \& Sheldon 2011, Price et al. 2013).

Lipopolysaccharide infusion in the ewe disrupted the pre-ovulatory rise in oestradiol; however, this was not always associated with inhibited LH pulsatility, suggesting that the effects of LPS are not solely neuroendocrine in nature (Battaglia et al. 2000). In support of direct ovarian effects, LPS has been shown to inhibit follicular steroidogenesis in vitro. LPS supressed bovine granulosa cell production of oestradiol (Shimizu et al. 2012), while progesterone production did not change in response to LPS. In contrast, LH-stimulated or luteinising bovine theca cells responded to LPS challenge with reduced progesterone production (Magata et al. 2014, Shimizu et al. 2016), suggesting a greater sensitivity of theca cells to LPS during luteinisation. Conversely, LPS stimulated progesterone production by bovine luteal cells in vitro, although there was no additive effect of LH and LPS (Grant et al. 2007). Collectively, this would indicate that luteal steroidogenesis is not adversely sensitive to LPS. In the current study, there is an apparent discrepancy between 
the lack of effect of LPS on progesterone production in vitro and reduced luteal progesterone content in RTID cows ex vivo. However, a possible explanation is that the reduced luteal vasculature resulted in decreased gonadotrophin or nutrient availability such that progesterone synthesis capabilities were reduced. Alternatively, PAMPs from the infected uterus could have suppressed hypothalamuspituitary gland function, thus decreasing luteal support. Furthermore, adverse alterations to follicle growth in response to LPS may also impact subsequent luteal function.

In the present study, TLR2 ligands failed to induce changes in steroidogenesis or angiogenesis. In contrast, challenge with TLR2 ligands, LTA or Pam3CSK4, led to an inflammatory response in bovine granulosa cells of both developing and dominant follicles (Bromfield \& Sheldon 2011, Price et al. 2013) and the accumulation of inflammatory mediators, IL6 and IL8. Oestradiol production was reduced concurrent with this inflammatory response, although progesterone was unaffected (Price et al. 2013). PGN also decreased oestradiol production in granulosa cells from large but not small bovine follicles (Shimizu et al. 2012). It remains to be established whether the LH surge and luteinisation alter the sensitivity to some PAMPs or whether TLR2 signalling only targets steroidogenesis downstream of progesterone.

The specificity of endothelial response to LPS and not LTA or PGN suggests that TLR4 signalling is a more critical regulator of luteal angiogenesis than TLR2 signalling. Alternatively, LPS signalling may be acting via downstream pathways exclusively induced by TLR4, rather than those common to all TLRs, namely those mediated by the downstream effector MyD88. This could include the activation of the interferon response factor 3 by LPS in a MyD88-independent manner which upregulates type 1 interferons (Dauphinee \& Karsan 2006), which have been shown to inhibit angiogenesis (Yildirim et al. 2015). The lack of response to TLR2 is not thought to be the result of the absence of heterodimerisation partners TLR1 or 6, since mRNA expression of both TLRs was detected in bovine luteal tissue (Nicholls et al. 2016, Gadsby et al. 2017).

LPS failed to evoke a response in the presence of TAK242, which is a selective small molecule inhibitor of TLR4. TAK242 potently inhibits the intracellular domain interactions of TLR4 without any effect on other TLRs (Kawamoto et al. 2008) and inhibits both MyD88dependent and independent pathways (Takashima et al. 2009) irrespective of LPS concentration. This suggests that the luteal actions of LPS are mediated via TLR4, rather than other cellular pathways (Hagar et al. 2013, Kayagaki et al. 2013). Interestingly, treatment with TAK242 reduced total EC area in the absence of LPS. The exact mechanism is unclear; however, it suggests the presence of underlying endogenous TLR4 activity and this may be LPS-independent. Indeed, alternative ligands including saturated and polyunsaturated fatty acids (e.g. palmitic acid and linoleic acid) can activate TLR4 and the subsequent effects are variable and complex (Rogero \& Calder 2018).

Angiogenesis is inhibited in response to LPS; however, it remains unclear whether this is as a result of LPS sensing directly by endothelial cells or indirectly via luteal steroidogenic cells. TLR4 has been immunolocalised to both EC and steroidogenic cells in bovine CL (Luttgenau et al. 2016), and both endothelial cells and granulosa cells and cell lines (Munshi et al. 2002, Herath et al. 2007, Zuo et al. 2017) express TLR4, supporting both possible cellular responses.

LPS has been shown to injure endothelium from a range of tissues (Koide et al. 1996, Fujita et al. 1998) and to lead to pathological cell damage, including during sepsis (Hotchkiss et al. 1999). Furthermore, LPS induced endothelial apoptosis via the activation of caspasemediated cell death pathways and up-regulation of proapoptotic signalling in vitro (Munshi et al. 2002). In the present study, LPS-induced endothelial cell loss resulted from a combination of increased apoptosis and reduced proliferation. LPS has been shown to inhibit neural progenitor cell proliferation (Ekdahl et al. 2003) and to suppress critical mediators of cell cycle progression (Cohn et al. 2010). The number of viable bovine luteal cells was reduced in response to short-term LPS treatment (Grant et al. 2007), while in contrast, LPS did not alter the survival of developing or luteinising bovine theca or granulosa cells over $96 \mathrm{~h}$ of culture (Shimizu et al. 2012, 2016, Magata et al. 2014).

In conclusion, the present study will be instrumental in developing new thinking into the mechanisms by which the TLR4 agonist LPS adversely affect ovarian function. Specifically, RTID profoundly reduced luteal vascularity in animals that had previously ovulated, while LPS dramatically decreased the ability of primary endothelial cells to form networks, even in the presence of exogenously-added pro-angiogenic factors. At the same time, LPS had no detectable effect on progesterone production or steroidogenic protein expression. This strongly indicates that ovarian endothelial cells are targeted by LPS and that they are particularly sensitive to even low concentrations of LPS. Equally, it is entirely feasible that 
LPS would adversely affect follicular endothelial cells, thereby reducing follicular competence. The evidence provided in this novel study on the direct impact of LPS on the functional development of the previously neglected CL is a major expansion of our understanding of the mechanisms by which bacterial infections have detrimental effects on ovarian function and fertility.

\section{Declaration of interest}

The authors declare that there is no conflict of interest that could be perceived as prejudicing the impartiality of the research reported.

\section{Funding}

Z A M was funded by Ministry of Higher Education and Scientific Research/ Kurdistan regional government. KJ W was funded by Faculty of Medicine and School of Veterinary Medicine and Science, The University of Nottingham and The Society for Reproduction and Fertility.

\section{Acknowledgment}

The authors are grateful to the staff of The University of Nottingham for their assistance with sample collection.

\section{References}

Akira S, Uematsu S \& Takeuchi O 2006 Pathogen recognition and innate immunity. Cell 124 783-801. (https://doi.org/10.1016/j. cell.2006.02.015)

Ali I, Nanchal R, Husnain F, Audi S, Konduri GG, Densmore JC, Medhora M \& Jacobs ER 2013 Hypoxia preconditioning increases survival and decreases expression of toll-like receptor 4 in pulmonary artery endothelial cells exposed to lipopolysaccharide. Pulmonary Circulation 3 578-588. (https://doi.org/10.1086/674337)

Alon T, Hemo I, Itin A, Pe'er J, Stone J \& Keshet E 1995 Vascular endothelial growth factor acts as a survival factor for newly formed retinal vessels and has implications for retinopathy of prematurity. Nature Medicine 1 1024-1028. (https://doi.org/10.1038/nm1095-1024)

Bannerman DD, Sathyamoorthy M \& Goldblum SE 1998 Bacterial lipopolysaccharide disrupts endothelial monolayer integrity and survival signaling events through caspase cleavage of adherens junction proteins. Journal of Biological Chemistry 273 35371-35380. (https://doi.org/10.1074/jbc.273.52.35371)

Battaglia DF, Krasa HB, Padmanabhan V, Viguié C \& Karsch FJ 2000 Endocrine alterations that underlie endotoxin-induced disruption of the follicular phase in Ewes1. Biology of Reproduction 62 45-53. (https://doi.org/10.1095/biolreprod62.1.45)

Bondurant RH 1999 Inflammation in the bovine female reproductive tract. Journal of Animal Science $\mathbf{7 7}$ (Supplement 2) 101-110. (https:// doi.org/10.2527/1999.77suppl_2101x)

Bonnin P, Huynh L, Haridon RL, Chene N \& Martal J 1999 Transport of uterine PGF2 $\alpha$ to the ovaries by systemic circulation and local lymphovenous-arterial diffusion during luteolysis in sheep. Reproduction 116 199-210. (https://doi.org/10.1530/jrf.0.1160199)

Borges AM, Healey GD \& Sheldon IM 2012 Explants of intact endometrium to model bovine innate immunity and inflammation ex vivo. American Journal of Reproductive Immunology 67 526-539. (https://doi.org/10.1111/j.1600-0897.2012.01106.x)

Bromfield JJ \& Sheldon IM 2011 Lipopolysaccharide initiates inflammation in bovine granulosa cells via the TLR4 pathway and perturbs oocyte meiotic progression in vitro. Endocrinology $\mathbf{1 5 2}$ 5029-5040. (https://doi.org/10.1210/en.2011-1124)

Chen Y, Lu N, Ling Y, Gao Y, Wang L, Sun Y, Qi Q, Feng F, Liu W, Liu W, et al. 2009 Wogonoside inhibits lipopolysaccharide-induced angiogenesis in vitro and in vivo via toll-like receptor 4 signal transduction. Toxicology 259 10-17. (https://doi.org/10.1016/j.tox.2009.01.010)

Cohn ZJ, Kim A, Huang L, Brand J \& Wang H 2010 Lipopolysaccharideinduced inflammation attenuates taste progenitor cell proliferation and shortens the life span of taste bud cells. BMC Neuroscience 1172. (https://doi.org/10.1186/1471-2202-11-72)

Couet J, Martel C, Dupont E, Luu-The VAN, Sirard MA, Zhao HF, Pelletier G \& Labrie F 1990 Changes in 3ß-hydroxysteroid dehydrogenase/ $\Delta 5-\Delta 4$ isomerase messenger ribonucleic acid, activity and protein levels during the estrous cycle in the bovine ovary. Endocrinology 127 2141-2148. (https://doi.org/10.1210/endo-127-5-2141)

Dauphinee SM \& Karsan A 2006 Lipopolysaccharide signaling in endothelial cells. Laboratory Investigation 86 9-22. (https://doi. org/10.1038/labinvest.3700366)

Ekdahl CT, Claasen JH, Bonde S, Kokaia Z \& Lindvall O 2003 Inflammation is detrimental for neurogenesis in adult brain. PNAS 100 13632-13637. (https://doi.org/10.1073/pnas.2234031100)

Fadhillah, Yoshioka S, Nishimura R \& Okuda K 2014 Hypoxia promotes progesterone synthesis during luteinization in bovine granulosa cells. Journal of Reproduction and Development 60 194-201. (https://doi. org/10.1262/jrd.2014-014)

Ferrara N, Gerber HP \& LeCouter J 2003 The biology of VEGF and its receptors. Nature Medicine 9 669-676. (https://doi.org/10.1038/ nm0603-669)

Frey EA \& Finlay BB 1998 Lipopolysaccharide induces apoptosis in a bovine endothelial cell line via a soluble CD14 dependent pathway. Microbial Pathogenesis 24 101-109. (https://doi.org/10.1006/ mpat.1997.0178)

Fujita M, Kuwano K, Kunitake R, Hagimoto N, Miyazaki H, Kaneko Y, Kawasaki M, Maeyama T \& Hara N 1998 Endothelial cell apoptosis in lipopolysaccharide-induced lung injury in mice. International Archives of Allergy and Immunology 117 202-208. (https://doi. org/10.1159/000024011)

Gabler C, Drillich M, Fischer C, Holder C, Heuwieser W \& Einspanier R 2009 Endometrial expression of selected transcripts involved in prostaglandin synthesis in cows with endometritis. Theriogenology 71 993-1004. (https://doi.org/10.1016/j.theriogenology.2008.11.009)

Gadsby JE, Tyson Nipper AM, Faircloth HA, D'Annibale-Tolhurst M, Chang J, Farin PW, Sheldon IM \& Poole DH 2017 Toll-like receptor and related cytokine mRNA expression in bovine corpora lutea during the oestrous cycle and pregnancy. Reproduction in Domestic Animals 52 495-504. (https://doi.org/10.1111/rda.12940)

Gilbert RO, Shin ST, Guard CL, Erb HN \& Frajblat M 2005 Prevalence of endometritis and its effects on reproductive performance of dairy cows. Theriogenology 64 1879-1888. (https://doi.org/10.1016/j. theriogenology.2005.04.022)

Giuliodori MJ, Magnasco RP, Becu-Villalobos D, Lacau-Mengido IM, Risco CA \& de la Sota RL 2013 Metritis in dairy cows: risk factors and reproductive performance. Journal of Dairy Science 96 3621-3631. (https://doi.org/10.3168/jds.2012-5922)

Grant E, Lilly ST, Herath S \& Sheldon IM 2007 Escherichia coli lipopolysaccharide modulates bovine luteal cell function. Veterinary Record 161 695-696. (https://doi.org/10.1136/vr.161.20.695)

Grote K, Schuett H, Salguero G, Grothusen C, Jagielska J, Drexler H, Muhlradt PF \& Schieffer B 2010 Toll-like receptor 2/6 stimulation promotes angiogenesis via GM-CSF as a potential strategy for immune defense and tissue regeneration. Blood 115 2543-2552. (https://doi. org/10.1182/blood-2009-05-224402 https://joe.bioscientifica.com https://doi.org/10.1530/JOE-19-0443 (c) 2020 Society for Endocrinology Published by Bioscientifica Ltd. Printed in Great Britain 
Hagar JA, Powell DA, Aachoui Y, Ernst RK \& Miao EA 2013 Cytoplasmic LPS activates caspase-11: implications in TLR4-independent endotoxic shock. Science 341 1250-1253. (https://doi.org/10.1126/ science.1240988)

Herath S, Williams EJ, Lilly ST, Gilbert RO, Dobson H, Bryant CE \& Sheldon IM 2007 Ovarian follicular cells have innate immune capabilities that modulate their endocrine function. Reproduction $\mathbf{1 3 4}$ 683-693. (https://doi.org/10.1530/REP-07-0229)

Hernandez-Gonzalez I, Gonzalez-Robayna I, Shimada M, Wayne CM, Ochsner SA, White L \& Richards JS 2006 Gene expression profiles of cumulus cell oocyte complexes during ovulation reveal cumulus cells express neuronal and immune-related genes: does this expand their role in the ovulation process? Molecular Endocrinology 20 1300-1321. (https://doi.org/10.1210/me.2005-0420)

Herzog K, Struve K, Kastelic JP, Piechotta M, Ulbrich SE, Pfarrer C Shirasuna K, Shimizu T, Miyamoto A \& Bollwein H 2012 Escherichia coli lipopolysaccharide administration transiently suppresses luteal structure and function in diestrous cows. Reproduction 144 467-476. (https://doi.org/10.1530/REP-12-0138)

Hotchkiss RS, Swanson PE, Freeman BD, Tinsley KW, Cobb JP, Matuschak GM, Buchman TG \& Karl IE 1999 Apoptotic cell death in patients with sepsis, shock, and multiple organ dysfunction. Critical Care Medicine 27 1230-1251. (https://doi.org/10.1097/00003246199907000-00002)

Ireland JJ, Murphee RL \& Coulson PB 1980 Accuracy of predicting stages of bovine estrous cycle by gross appearance of the corpus luteum. Journal of Dairy Science 63 155-160. (https://doi.org/10.3168/jds. S0022-0302(80)82901-8)

Kawamoto T, Ii M, Kitazaki T, Iizawa Y \& Kimura H 2008 TAK-242 selectively suppresses toll-like receptor 4-signaling mediated by the intracellular domain. European Journal of Pharmacology 584 40-48. (https://doi.org/10.1016/j.ejphar.2008.01.026)

Kayagaki N, Wong MT, Stowe IB, Ramani SR, Gonzalez LC, AkashiTakamura S, Miyake K, Zhang J, Lee WP, Muszyński A, et al. 2013 Noncanonical inflammasome activation by intracellular LPS independent of TLR4. Science 341 1246-1249. (https://doi. org/10.1126/science.1240248)

Knickerbocker JJ, Wiltbank MC \& Niswender GD 1988 Mechanisms of luteolysis in domestic livestock. Domestic Animal Endocrinology 5 91-107. (https://doi.org/10.1016/07397240(88)90011-2)

Koide N, Abe K, Narita K, Kato Y, Sugiyama T, Jiang GZ \& Yokochi T 1996 Apoptotic cell death of vascular endothelial cells and renal tubular cells in the generalized Shwartzman reaction. FEMS Immunology and Medical Microbiology 16 205-211. (https://doi.org/10.1111/j.1574695X.1996.tb00137.x)

Lavon Y, Leitner G, Moallem U, Klipper E, Voet H, Jacoby S, Glick G, Meidan R \& Wolfenson D 2011 Immediate and carryover effects of Gram-negative and Gram-positive toxin-induced mastitis on follicular function in dairy cows. Theriogenology 76 942-953. (https://doi. org/10.1016/j.theriogenology.2011.05.001)

Luttgenau J, Lingemann B, Wellnitz O, Hankele AK, Schmicke M, Ulbrich SE, Bruckmaier RM \& Bollwein H 2016 Repeated intrauterine infusions of lipopolysaccharide alter gene expression and lifespan of the bovine corpus luteum. Journal of Dairy Science 99 6639-6653. (https://doi.org/10.3168/jds.2015-10806)

Ma B, Dohle E, Li M \& Kirkpatrick CJ 2017 TLR4 stimulation by LPS enhances angiogenesis in a co-culture system consisting of primary human osteoblasts and outgrowth endothelial cells. Journal of Tissue Engineering and Regenerative Medicine 11 1779-1791. (https://doi. org/10.1002/term.2075)

Magata F, Horiuchi M, Miyamoto A \& Shimizu T 2014 Lipopolysaccharide (LPS) inhibits steroid production in theca cells of bovine follicles in vitro: distinct effect of LPS on theca cell function in pre- and postselection follicles. Journal of Reproduction and Development 60 280-287. (https://doi.org/10.1262/jrd.2013-124)
Mann GE 2009 Corpus luteum size and plasma progesterone concentration in cows. Animal Reproduction Science 115 296-299. (https://doi.org/10.1016/j.anireprosci.2008.11.006)

Mann GE \& Lamming GE 2001 Relationship between maternal endocrine environment, early embryo development and inhibition of the luteolytic mechanism in cows. Reproduction 121 175-180. (https:// doi.org/10.1530/rep.0.1210175)

Mateus L, da Costa LL, Bernardo F \& Silva JR 2002 Influence of puerperal uterine infection on uterine involution and postpartum ovarian activity in dairy cows. Reproduction in Domestic Animals 37 31-35. (https://doi.org/10.1046/j.1439-0531.2002.00317.x)

Mateus L, Lopes da Costa L, Diniz P \& Ziecik AJ 2003 Relationship between endotoxin and prostaglandin (PGE2 and PGFM) concentrations and ovarian function in dairy cows with puerperal endometritis. Animal Reproduction Science 76 143-154. (https://doi. org/10.1016/s0378-4320(02)00248-8)

McDougall S 2001 Effect of intrauterine antibiotic treatment on reproductive performance of dairy cows following periparturient disease. New Zealand Veterinary Journal 49 150-158. (https://doi.org/1 $0.1080 / 00480169.2001 .36223)$

Mohammed ZA, Mann GE \& Robinson RS 2019 Impact of endometritis on post-partum ovarian cyclicity in dairy cows. Veterinary Journal $\mathbf{2 4 8}$ 8-13. (https://doi.org/10.1016/j.tvj1.2019.03.008)

Munshi N, Fernandis AZ, Cherla RP, Park IW \& Ganju RK 2002 Lipopolysaccharide-induced apoptosis of endothelial cells and its inhibition by vascular endothelial growth factor. Journal of Immunology 168 5860-5866. (https://doi.org/10.4049/ jimmunol.168.11.5860)

Nicholls A, Payne L, Robinson RS, Coffey T \& Woad KJ 2016 Disease takes its Toll on reproduction: toll-like receptors and the bovine corpus luteum. Reproduction Abstracts 3 P037. (https://doi.org/10.1530/ repabs.3.P037)

Nwachukwu CU 2019 The role and regulation of angiogenesis during key stages of ovarian follicle development. PhD thesis. Nottingham, UK: University of Nottingham. (available at: http://eprints.nottingham. ac.uk/id/eprint/56432)

Pescador N, Soumano K, Stocco DM, Price CA \& Murphy BD 1996 Steroidogenic acute regulatory protein in bovine corpora lutea. Biology of Reproduction 55 485-491. (https://doi.org/10.1095/ biolreprod55.2.485)

Plendl J, Neumüller C \& Sinowatz F 1996 Differences of microvascular endothelium in the bovine corpus luterum of pregnancy and the corpus luteum of the estrous cycle. Biology of the Cell 87 179-188. (https://doi.org/10.1111/j.1768-322X.1996.tb00979.x)

Price JC, Bromfield JJ \& Sheldon IM 2013 Pathogen-associated molecular patterns initiate inflammation and perturb the endocrine function of bovine granulosa cells From ovarian dominant follicles via TLR2 and TLR4 pathways. Endocrinology 154 3377-3386. (https://doi. org/10.1210/en.2013-1102)

Robinson RS, Hammond AJ, Nicklin LT, Schams D, Mann GE \& Hunter MG 2006 Endocrine and cellular characteristics of corpora lutea from cows with a delayed post-ovulatory progesterone rise. Domestic Animal Endocrinology 31 154-172. (https://doi.org/10.1016/j. domaniend.2005.10.003)

Robinson RS, Hammond AJ, Mann GE \& Hunter MG 2008 A novel physiological culture system that mimics luteal angiogenesis. Reproduction 135 405-413. (https://doi.org/10.1530/REP-07-0370)

Robinson RS, Woad KJ, Hammond AJ, Laird M, Hunter MG \& Mann GE 2009 Angiogenesis and vascular function in the ovary. Reproduction 138 869-881. (https://doi.org/10.1530/REP-09-0283)

Rogero MM \& Calder PC 2018 Obesity, inflammation, toll-like receptor 4 and fatty acids. Nutrients 10 432. (https://doi.org/10.3390/ nu10040432)

Saber T, Veale DJ, Balogh E, McCormick J, NicAnUltaigh S, Connolly M \& Fearon U 2011 Toll-like receptor 2 induced angiogenesis and invasion is mediated through the Tie 2 signalling pathway in rheumatoid https://joe.bioscientifica.com

https://doi.org/10.1530/JOE-19-0443
(C) 2020 Society for Endocrinology Published by Bioscientifica Ltd. Printed in Great Britain 
arthritis. PLoS ONE 6 e23540. (https://doi.org/10.1371/journal. pone.0023540)

Schneider CA, Rasband WS \& Eliceiri KW 2012 NIH Image to ImageJ: 25 years of image analysis. Nature Methods 9 671-675. (https://doi. org/10.1038/nmeth.2089)

Sheldon IM, Noakes DE, Rycroft AN, Pfeiffer DU \& Dobson H 2002 Influence of uterine bacterial contamination after parturition on ovarian dominant follicle selection and follicle growth and function in cattle. Reproduction 123 837-845. (https://doi.org/10.1530/ rep.0.1230837)

Sheldon IM, Cronin J, Goetze L, Donofrio G \& Schuberth HJ 2009 Defining postpartum uterine disease and the mechanisms of infection and immunity in the female reproductive tract in cattle. Biology of Reproduction 81 1025-1032. (https://doi.org/10.1095/ biolreprod.109.077370)

Shimada M, Hernandez-Gonzalez I, Gonzalez-Robanya I \& Richards JS 2006 Induced expression of pattern recognition receptors in cumulus oocyte complexes: novel evidence for innate immune-like functions during ovulation. Molecular Endocrinology 20 3228-3239. (https://doi. org/10.1210/me.2006-0194)

Shimizu T, Echizenya R \& Miyamoto A 2016 Effect of lipopolysaccharide on progesterone production during luteinization of granulosa and theca cells in vitro. Journal of Biochemical and Molecular Toxicology 30 206-211. (https://doi.org/10.1002/jbt.21783)

Shimizu T, Miyauchi K, Shirasuna K, Bollwein H, Magata F, Murayama C \& Miyamoto A 2012 Effects of lipopolysaccharide (LPS) and peptidoglycan (PGN) on estradiol production in bovine granulosa cells from small and large follicles. Toxicology In Vitro 26 1134-1142. (https://doi.org/10.1016/j.tiv.2012.06.014)

Shin MR, Kang SK, Kim YS, Lee SY, Hong SC \& Kim EC 2015 TNF-alpha and LPS activate angiogenesis via VEGF and SIRT1 signalling in human dental pulp cells. International Endodontic Journal 48 705-716. (https://doi.org/10.1111/iej.12396)

Takashima K, Matsunaga N, Yoshimatsu M, Hazeki K, Kaisho T, Uekata M, Hazeki O, Akira S, Iizawa Y \& Ii M 2009 Analysis of binding site for the novel small-molecule TLR4 signal transduction inhibitor TAK242 and its therapeutic effect on mouse sepsis model. British Journal of Pharmacology 157 1250-1262. (https://doi.org/10.1111/j.14765381.2009.00297.x)

Tsang PC, Walton JS \& Hansel W 1990 Oxytocin-specific RNA, oxytocin and progesterone concentrations in corpora lutea of heifers treated with oxytocin. Journal of Reproduction and Fertility 89 77-84. (https:// doi.org/10.1530/jrf.0.0890077)
Williams EJ, Fischer DP, Noakes DE, England GCW, Rycroft A, Dobson H \& Sheldon IM 2007 The relationship between uterine pathogen growth density and ovarian function in the postpartum dairy cow. Theriogenology 68 549-559. (https://doi.org/10.1016/j. theriogenology.2007.04.056)

Williams EJ, Sibley K, Miller AN, Lane EA, Fishwick J, Nash DM, Herath S, England GC, Dobson H \& Sheldon IM 2008 The effect of Escherichia coli lipopolysaccharide and tumour necrosis factor alpha on ovarian function. American Journal of Reproductive Immunology 60 462-473. (https://doi.org/10.1111/j.16000897.2008.00645.x)

Woad KJ \& Robinson RS 2016 Luteal angiogenesis and its control. Theriogenology 86 221-228. (https://doi.org/10.1016/j. theriogenology.2016.04.035)

Woad KJ, Hunter MG, Mann GE, Laird M, Hammond AJ \& Robinson RS 2012 Fibroblast growth factor 2 is a key determinant of vascular sprouting during bovine luteal angiogenesis. Reproduction 143 35-43. (https://doi.org/10.1530/REP-11-0277)

Xia S, Menden HL, Korfhagen TR, Kume T \& Sampath V 2018 Endothelial immune activation programmes cell-fate decisions and angiogenesis by inducing angiogenesis regulator DLL4 through TLR4-ERKFOXC2 signalling. Journal of Physiology 596 1397-1417. (https://doi. org/10.1113/JP275453)

Yildirim C, Favre J, Weijers EM, Fontijn RD, van Wijhe MH, van Vliet SJ, Boon RA, Koolwijk P, van der Pouw Kraan TC \& Horrevoets AJ 2015 IFN-beta affects the angiogenic potential of circulating angiogenic cells by activating calpain 1. American Journal of Physiology: Heart and Circulatory Physiology 309 H1667-H1678. (https://doi.org/10.1152/ ajpheart.00810.2014)

Zhou M, McFarland-Mancini MM, Funk HM, Husseinzadeh N, Mounajjed T \& Drew AF 2009 Toll-like receptor expression in normal ovary and ovarian tumors. Cancer Immunology, Immunotherapy $\mathbf{5 8}$ 1375-1385. (https://doi.org/10.1007/s00262-008-0650-y)

Zielniok K, Motyl T \& Gajewska M 2014 Functional interactions between 17beta-estradiol and progesterone regulate autophagy during acini formation by bovine mammary epithelial cells in 3D cultures. BioMed Research International 2014 382653. (https://doi. org/10.1155/2014/382653)

Zuo T, Zhu M, Xu W, Wang Z \& Song H 2017 Iridoids with genipin stem nucleus inhibit lipopolysaccharide-induced inflammation and oxidative stress by blocking the NF- $\mathrm{kB}$ pathway in polycystic ovary syndrome. Cellular Physiology and Biochemistry 43 1855-1865. (https:// doi.org/10.1159/000484074)

Received in final form 22 January 2020

Accepted 27 January 2020

Accepted Manuscript published online 30 January 2020
(C) 2020 Society for Endocrinology Published by Bioscientifica Ltd. 